\title{
Implementing Knowledge Management System to Improve Effectiveness of Faculty Activities
}

\author{
Matheus Supriyanto Rumetna ${ }^{1}$, Tirsa Ninia Lina ${ }^{2}$, Ratna Rosmauli Pakpahan ${ }^{3}$, Arce \\ Yulita Ferdinandus ${ }^{4}$, Frenny Silvia Pormes ${ }^{5}$, Joseph Eliza Lopulalan ${ }^{6}$ \\ ${ }^{1,2}$ The Faculty of Computer Sciences, Victory University of Sorong,Sorong, Indonesia, ${ }^{3,6}$ The Faculty of \\ Social Science,Victory University of Sorong, Sorong, Indonesia, ${ }^{4}$ The Faculty of Business and \\ Economics, Victory University of Sorong, Sorong, Indonesia, ${ }^{5}$ The Faculty of Teacher Training and \\ Education,Victory University of Sorong, Sorong, Indonesia \\ *matheus.rumetna@gmail.com
}

\begin{abstract}
Higher education is an example of organizations that could manage knowledge in its creation, transfer and dissemination. A frequently occurring problem found in higher education faculties is knowledge documentation. For that reason, knowledge management is necessarily needed to overcome the documentation problem as well as to improve academic staff's performance. Another problem faced by faculties is the loss of knowledge. The loss of knowledge may be caused by an ending of student's study period, a change in organizational structure, and a turnover among lecturers, staff and other sources of knowledge. The aim of this research, therefore, is to provide a review and insights regarding the benefits of implementing Knowledge Management System in higher education faculties. The methods employed in the research were the qualitative method and the 10-step knowledge management roadmap. The research produced a concept of Knowledge Management System which could be utilized as a reference to improve effectiveness of faculty activities.
\end{abstract}

Keywords: Knowledge Management System; Knowledge Management Roadmap; Higher Education; Effectiveness of Faculty Activities

\section{Introduction}

Information and Communications Technology (ICT) belongs to the fastest growing industries, providing both threats and opportunities for an organization [1],[2],[3],[4]. As it has become one of key successes for organizations to flourish, therefore, the question one should ask is how could we benefit from it? Information, whether in form of standard procedure and policy documentation, has become a critical part in organization so that it should be well managed and utilized as knowledge that has business value [5].

The increasingly strict, competitive condition in the globalization era has driven us to shift our paradigm from the resource-based competitiveness to knowledge-based competitiveness. Both paradigms are contradictory as the first paradigm is grounded upon the location and geographical condition of superior natural resources while the second one is based on knowledge and technology as well as human resources development in organization. In order to develop human resources in organization more easily, an ability to manage and develop 
existing knowledge is needed. Knowledge management could be a reliable support for an organization to improve its competitiveness [6].

Knowledge management will play a critical role when an organization needs a structured knowledge management and reservation. Tiwana suggests that there are 24 reasons to adopt Knowledge Management. Some of them are a need to prevent costly, repeated mistakes, a need to prevent unnecessary reinvention, a need to anticipate accurate prediction and a need which emerges as a competitive response [7].

Higher education is an example of organizations that could manage knowledge in its creation, transfer and dissemination. In its creation, knowledge could be acquired from researches and studies that will add value to academic productivity. Through researches, new discovery will be made [8]. In higher education, a frequently occurring problem in each faculty is knowledge documentation.

Higher education faculties acknowledge the importance of documenting data and information which could support their activities. Without documentation, a great amount of knowledge provided by academic staff will be lost and the same old mistakes will likely be repeated. The loss of knowledge can be caused by an ending of student's study period, a change in organizational structure and a turnover among lecturers, staff or other sources of knowledge [8]. In this situation, knowledge management is needed to prevent the loss of knowledge through documentation and improve academic staff' performance quality [6].

Based on our analysis result, there are various, important knowledge which could support and sustain faculty activities. Moreover, the objective of documenting knowledge is to preserve knowledge generated by academic staff and share them to other staff, building a means of discussing and distributing problems. Without a management system, a faculty's attempt to utilize knowledge will not be effective. Knowledge possessed by a faculty can be developed and structured into a Knowledge Management System (KMS).

Implementing KMS with the aid of Information and Communications Technology is expected to improve the knowledge documentation, dissemination, adoption, development and creation. Also, KMS is needed to maintain and improve competitiveness. The aims of this research are to provide a review and insights regarding the benefits of implementing KMS for faculties and to develop a concept of KMS which could be utilized as a reference to improve effectiveness of faculty activities.

\subsection{Literature Review}

Puji Ratwiyanti and Rahman Rosyidi in 2018 conducted a research under the title "A Knowledge Management System Architecture for Students Activities Unit (UKM) and Student Organizations (ORMA) in STMIK AMIKOM Purwokerto". The research attempted to design a KMS architecture for the UKM and ORMA in STMIK AMIKOM Purwokerto. The research employed the 10-step Knowledge Management Roadmap method by Amrit Tiwana and the Centralized and Decentralized Knowledge Management Architecture method by Ronald Maier. However, in their research, only the first four steps of the 10-Step Knowledge Management Roadmap were used in order to identify any existing knowledge, therefore making it easier to develop a correct KMS architecture. The research resulted in a blueprint of a KMS architecture [9].

Kornkanok and Massudi in 2019 in a research entitled "Knowledge and integrated the data management models for personalized intercropping in rubber plantation", discusses the selection and allocation of space for planting intercropping to maximize results and minimize costs for individual farmers using Multi-Criteria Decision Making ( MCDM). The problem faced is information that is not centralized, redundant data, to a variety of data formats. In addition, the knowledge possessed is related to selecting plants to be planted in rubber 
plantations appropriately, as well as tacit knowledge gained from the experiences of successful farmers and agricultural experts. This research uses an integrated Ontology-based knowledge and multi-objective optimization model for Decision Support Systems (or DSS) for intercropping, and also presents an integrated knowledge process to achieve knowledge modeling as an intercropping concept in rubber plantations. In addition, Intercropping Ontology as a basis for making decisions to recommend suitable species and list of plants. Using an ontology for DSS can help provide recommendations about suitable crops planted around the farmer's area according to rules-based inference that acts as logical reasoning. [10].

Noor et al, in 2019 conducted a study under the title "A review on cloud based knowledge management in higher education institutions". This study discusses KM that has been used by entrepreneurs to extract, distribute and use information systematically under KMS. The use of new technology in KMS was identified by researchers as one of the core issues. Cloud computing is the most widely adopted choice by entrepreneurs because it can reduce infrastructure and maintenance costs. Higher Education Institutions (HEIs) have also begun using KM to create and disseminate knowledge. Cloud-based KM attracts HEIs because it is able to update educational methods and objectives according to innovative trends in technology. This research highlights the benefits and challenges related to KMS and their impact on knowledge [11].

Unlike previous researches, this research attempted to develop a KMS concept for faculties to use which used the qualitative method and the 10-Step Knowledge Management Roadmap in its development. Moreover, the KMS would be designed as web application, therefore allowing more flexibility in its usage.

\subsection{Knowledge}

Knowledge is a combination of experiences, expert views, values, contextual information, and intuitions which provides an environment and framework to evaluate and uniting new experience with information. The knowledge is divided into two types namely Explicit Knowledge and Tacit Knowledge, which can be described as follows [12],[13]:

\section{1) Explicit Knowledge}

Knowledge which can be expressed via words and numbers and explained in scientific format, specification, manual, etc. This type of knowledge can be transferred from one individual to another formally and systematically. Explicit knowledge can also be explained as a business process, method procedure and pattern as well as design experience from a production.

\section{2) Tacit Knowledge}

Knowledge derived from experts, individually or collectively, and their experiences. Tacit knowledge is very personal and difficult to formulate, making it hard to be communicated or transferred to other individual. Personal feeling, intuition, gesture, physical experiences and rule of thumb belong to tacit knowledge.

\subsection{Knowledge Conversion}

Nonaka explains that the fundamental reason behind successful, Japanese organizations is that their skills and experiences are grounded on the creation of organizational knowledge. Knowledge creation can be achieved via introducing a synergic relation between tacit and explicit knowledge through the SECI process (Socialization, Externalization, Combination and Internalization). The process can be seen in Figure 1 [8],[13],[14]:

1) Socialization (Tacit to Tacit Knowledge). 
Knowledge is transferred from one individual to another in form of tacit knowledge. Socialization emerges from sharing activities and creates tacit knowledge from direct experiences.

2) Externalization (Tacit to Explicit Knowledge).

Externalization is a knowledge transformation from tacit to explicit forms. With externalization, tacit knowledge possessed by an individual is extracted and formulated into other media which allows others to study the knowledge more easily.

3) Combination (Explicit to Explicit Knowledge).

Combination is to organize a group of explicit knowledge into a more systematic media by adding new knowledge as well as combining and categorizing the accumulated knowledge. Knowledge combination can be facilitated with media such as documents, meeting, phone calls or computerized communication network, etc.

4) Internalization (Explicit to Tacit Knowledge).

Internalization is to transform knowledge from explicit to tacit formats. One example is practices in a learning process. When individual's experiences from socialization, externalization and combination are internalized into tacit knowledge through some methods, the knowledge becomes his valuable asset and gradually his new knowledge.

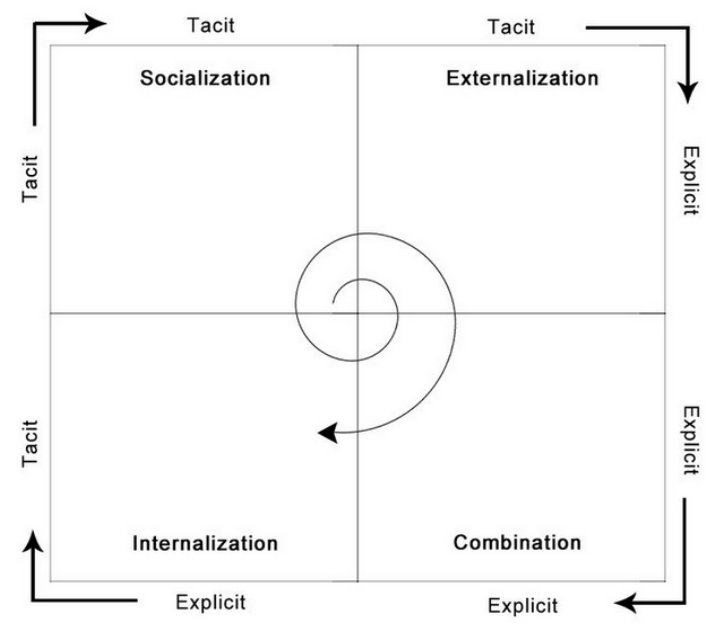

Figure 1. Knowledge Conversion

\subsection{Knowledge Management}

Each individual could define Knowledge Management uniquely. Therefore, there are different definitions of KM. According to Davenport, KM is a series of activities conducted by organizations to identify, create, explain and distribute knowledge to be re-used, identified and learned [15],[16].

Another defines KM as any attempt to develop useful knowledge in organizations. They can be: encouraging a communication culture between personnel, giving learning opportunities and promoting knowledge sharing. Those attempts could create and maintain 
values from the cores of the business competence by utilizing existing information technology [6].

Uriarte simply defines KM as a process which converts tacit into explicit knowledge and then shares it to members in organization. Moreover, Uriarte explains that KM is a process in which an organization creates values from organizational assets which are based on knowledge and intellectuals [14].

Therefore, in general, Knowledge Management is an activity which combines learning, change and innovation. KM entails human resource development and knowledge sharing efforts among staff who are vital assets in order to improve their capabilities to innovate. Managing knowledge is more about "an organization managing their employees than how long have they wasted time to perform organizational activities". This means that KM is about how people from different backgrounds starting sharing, which now is labelled with learning organization.

\subsection{Knowledge Management System}

Knowledge Management System is an integration of technology and mechanism which is developed to support the four Knowledge Management processes. KMS is classified into four as explained as follows [5],[13],[16]:

1) Knowledge Application System (KAS)

KAS supports process in which an individual may use other individual's knowledge without acquiring or learning it. A KM mechanism and technology may support KAS by facilitating routines and directions of a KM process. KAS depends on the routines and directions. A KM mechanism facilitates directions such as a hierarchical relationship, helpdesk and support center. It also facilitates routines such as organizational policies, work practices and standards. A KM technology supports direction and routine including expert system, decision support, system advisor, troubleshooting and help-desk.

2) Knowledge Capture System

Knowledge Capture System supports processes which depict both tacit and explicit knowledge which may be possessed by individuals, artifacts or organizational bodies. This system could help capturing existing knowledge both within and outside organizational boundaries. Knowledge Capture System depends on KM Mechanism and technology which support externalization and internalization. Model or prototype development and story articulation are few examples of KM mechanism which may allow externalization. Learning by observing and meeting are instances of KM mechanism which facilitate internalization. KM technology could also support knowledge capture by facilitating externalization and internalization. Externalization via knowledge reengineering is required to implement smart technology such as expert systems and case-based reasoning system. KM technology which facilitates internalization includes computer-based communication and simulation-based computer.

3) Knowledge Sharing System (KSS)

KSS could be defined as a system which allows organization members to receive tacit and explicit knowledge from each other. In a KSS, a knowledge owner will: share his/her knowledge with his/her reliable, controlled group, decide when to share it and in what condition as well as to search for fair exchange or reward in knowledge sharing.

4) Knowledge Discovery System (KDS) 
KDS supports a development of new tacit or explicit knowledge from new data and information or previous synthesis of knowledge. KDS depends on KM Mechanism and KM Technology which could support combination and socialization processes. KM mechanism in Knowledge Discovery System involves socialization process, facilitating a synthesis and integration of tacit knowledge between individuals.

\section{Methodology}

A qualitative method was employed in this research to produce good understanding and description of data [13],[17]. Next, the 10-step KM roadmap formulated by Amrit Tiwana was used to develop a KMS concept (see Figure 2) [18],[9],[19]. The roadmap is divided into four phases:

1) Infrastructure Evaluation

2) KMS Analysis, Design and Development

3) Deployment

4) Evaluation

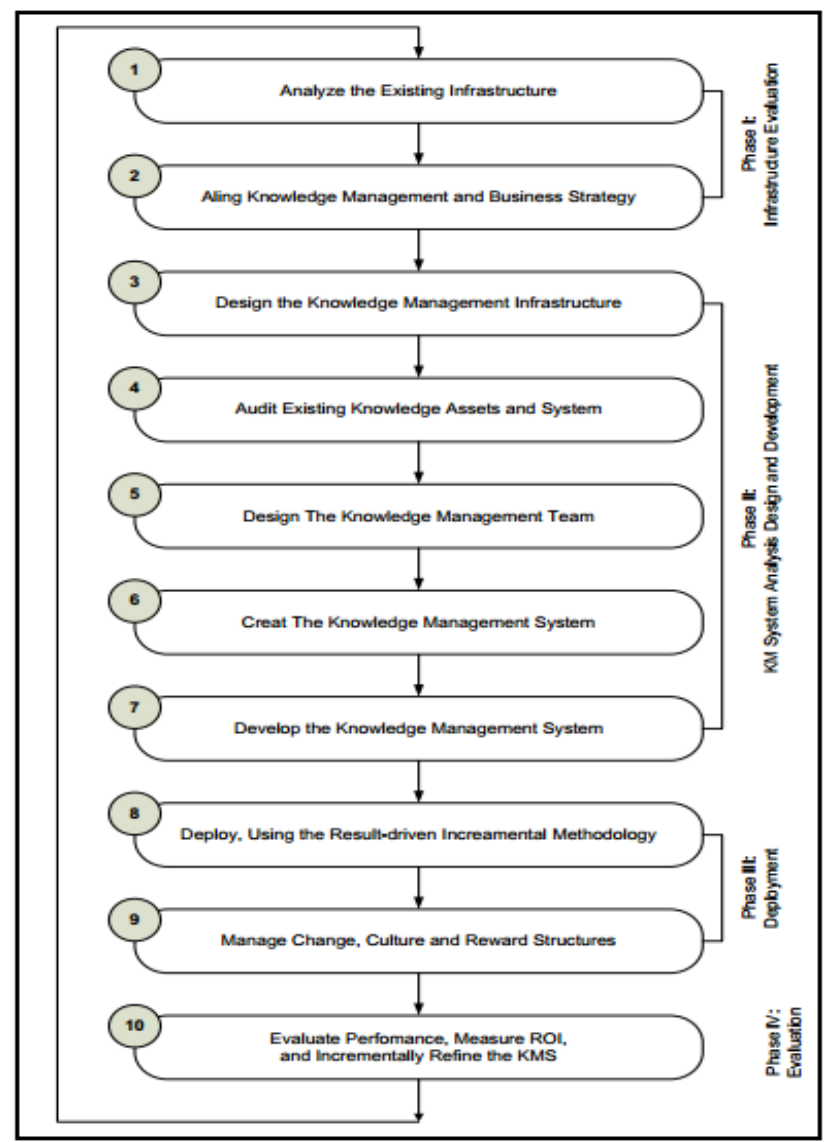

Figure 2. 10-Step Knowledge Management Roadmap 


\section{Result and Discussion}

Interviews [20],[21],[22],[23],[24] were performed with 50 respondents regarding problems faced during performing faculty activities, especially in knowledge documentation. The respondents were lecturers, staff and students of Victory University of Sorong. The interviews showed the information problems frequently faced by their faculties, the procedure of solving them as well as the regulation and the roles of the stakeholders.

After that, a literature review was conducted in which data were collected by searching and studying data from textbooks, journals and other references related to the research problem.

Next, the data acquired from the interview sessions and the literature review was analyzed to formulate a correct framework in developing our KMS concept/model. The model consisted of several factors required to meet the research objective: to improve effectiveness of faculty activities. The main feature of this KMS model is knowledge management. The knowledge itself is categorized into three types: Knowledge Base, which is a basic knowledge derived from written, formal knowledge; Best Practices, a type of knowledge which is derived from experts' experiences; and a knowledge which could be shared to all users.

The KMS model will perform like a search engine for documents which have been collected for this research. When a user inputs a search word in the KMS, the KMS will then display a list of documents containing the search word. The KMS will have two functions derived from KM to support document search: a preview function and thesaurus. The preview function will allow users to preview documents displayed according to their search words, making it easier to get the desired information, while the thesaurus function will facilitate information sources from experts.

The KMS will employ database and web application. A database model will be created since the system will process sentences and a sentence itself is a meaningful, fundamental grammar unit. This approach is necessary because all actors in the faculties need to know what is written in a document they want to find and how any word they will use in the search engine will be used in a sentence context. This is different from merely identifying documents which contain search words. In other words, search engine users may acquire information regarding any sentences containing their search words in documents being displayed. The preview function displays a preview of any document being displayed and points out relevant sentences in the document which contain any search word inputted by user. The structure of this KMS can be seen in Figure 3.

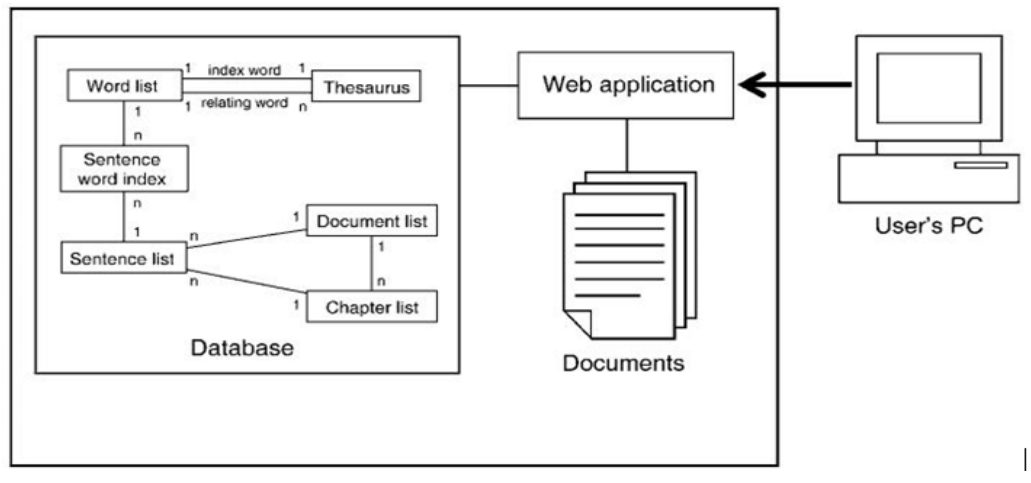

Figure 3. The Structure of Knowledge Management System 
Thesaurus is presented in form of a table of entry word. A relation between words and their scores show their relation power. They are inputted into the database and then, from them, a list of important keywords is developed collectively. Any relationship between keywords is identified and acknowledged as a relationship between notations. The relationship is related to words in the thesaurus under an assumption that there are a relationship between two words and an explanation based on their relationship in a document as well as notations which must be mentioned as sentences. Therefore, when there are two words which belong to a same sentence, then the words considered related. Next, the number of sentences that contain the related words is considered as its relationship power. Lastly, the number of sentences which contain the related words is recorded in the thesaurus as a score which indicates its relationship power.

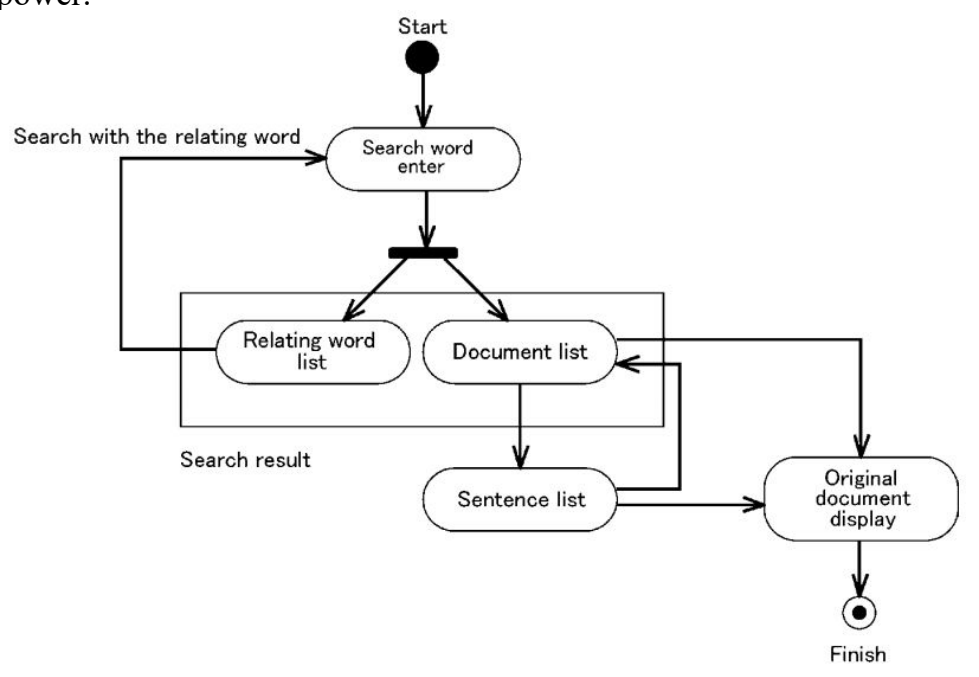

Figure 4. The Procedure for Using the KMS

Figure 4 displays the procedure for using the KMS. Starting when a user inputs a search word into the search engine, which is managed in local computer or network. The relationship between the searched words and the related words will be mentioned in the thesaurus. This is because each document displayed in the research result list is related to each original document file. And sentences in the generated list consist of a combination of searched words and any words related to them. Users will have the options whether to display the full document or a list of sentences in order to get further information regarding the search words they inputs.

\section{Conclusion}

The implementation of KMS with Communication and Information Technology can be a concept in optimizing knowledge documentation, dissemination, adoption, development and creation. This KMS concept could also improve the effectiveness of faculty activities which had been found filled with problems.

The KMS concept acknowledges sentences as a form of search words since users want to find original documents easily and quickly. The list of sentences is also effective to discover 
information they want to search. Besides that, users could also use the list of sentences to compare listed documents and examine different descriptions based on their search words contained in the listed documents.

A special emphasis is placed on determining whether the system could combine the preview function and search function so that any information regarding search words can be accessed and any relevant document could be displayed faster, and modify the thesaurus function so that it could also be used to search information. This concept is expected to feature the preview and thesaurus functions of the KMS in supporting the information source search in this case.

Further conceptual development will have the KMS to be able to support knowledge documentation not only in document format but also multimedia formats such as pictures, videos and links.

\section{Acknowledgment}

We sincerely give our thanks to the Information System Study Program, the Faculty of Computer Science, Victory University of Sorong, which has given the research permission, data and information used during the research process.

\section{References}

[1] M. S. Rumetna, T. N. Lina, and A. B. Santoso, "RANCANG BANGUN APLIKASI KOPERASI SIMPAN PINJAM MENGGUNAKAN METODE RESEARCH AND DEVELOPMENT," Tek. Mesin, Elektro dan Ilmu Komput., vol. 11, no. 1, pp. 119 $128,2020$.

[2] M. S. Rumetna, "Pemanfaatan Cloud Computing Pada Dunia Bisnis: Studi Literatur," J. Teknol. Inf. dan Ilmu Komput., vol. 5, no. 3, pp. 305-314, 2018.

[3] M. S. Rumetna and I. Sembiring, "PEMANFAATAN CLOUD COMPUTING BAGI USAHA KECIL MENENGAH (UKM)," in Prosiding Seminar Nasional Geotik, 2017, no. ISSN:2580-8796, pp. 1-9.

[4] T. N. Lina and Sem, "PENERAPAN METODE DECISION TREE UNTUK PENENTUAN NILAI PRINSIP-PRINSIP E-PROCUREMENT,” in Seminar Nasional GEOTIK, 2017, pp. 10-19.

[5] H. Sulaiman, "Knowledge Management System Service Center Berbasis Web," Fakt. Exacta, vol. 8, no. 3, pp. 220-230, 2015.

[6] W. Kurnia Sari and K. Ditha Tania, "Penerapan Knowledge Management System (KMS) Berbasis Web Studi Kasus Bagian Teknisi dan Jaringan Fakultas Ilmu Komputer Universitas Sriwijaya,” J. Sist. Inf., vol. 6, no. 2, pp. 681-688, 2014.

[7] L. J. Susanto and H. Kurniawan, "Penerapan Knowledge Management System Dalam Manajemen Data Kegiatan Hidroponik (Studi Kasus: Komunitas Hidroponik Bandar Lampung)," SIMADA (Jurnal Sist. Inf. Manaj. Basis Data), vol. 1, no. 1, pp. 1-10, 2018.

[8] A. E. Wijaya, "Model Penerapan Knowledge Management System Untuk Penyusunan Tugas Akhir Berbasis Teknologi Mobile Menggunakan J2Me ( Studi 
Kasus Stmik Subang ),” Semin. Nas. Inform. 2014 (semnasIF 2014), vol. 2014, no. semnasIF, pp. 190-195, 2014.

[9] P. Ratwiyanti and R. Rosyidi, "Arsitektur Knowledge Management System bagi Unit Kegiatan Mahasiswa (UKM) dan Organisasi Mahasiswa (ORMA) di STMIK Amikom Purwokerto," J. Pro Bisnis, vol. 11, no. 2, pp. 1-13, 2018.

[10] K. Phoksawat and M. Mahmuddin, "Knowledge and integrated data management model for personalized intercropping in rubber plantation," Int. J. Electr. Comput. Eng., vol. 9, no. 6, pp. 5502-5511, 2019.

[11] A. S. M. Noor, M. Younas, and M. Arshad, "A review on cloud based knowledge management in higher education institutions," Int. J. Electr. Comput. Eng., vol. 9, no. 6, pp. 5420-5427, 2019.

[12] H. Davenport, Thomas and L. Prusak, Working Knowledge: How Organization Manage What They Know, vol. 2, no. 5. Boston: Harvard Business School Press, 2009.

[13] T. N. Lina, D. Manongga, and A. Iriani, "PENERAPAN FRAMEWORK KNOWLEDGE MANAGEMENT PADA UKM KULIT PARI YOGYAKARTA," in Seminar Nasional GEOTIK, 2017, pp. 139-145.

[14] H. Saragih, T. Darmanto, B. Reza, and D. Setiyadi, "Sistem Informasi Knowledge Management Pada Perguruan Tinggi Stmik Widya Dharma Pontianak," J. Tek. dan Ilmu Komput., vol. 01, no. 03, pp. 423-437, 2012.

[15] N. Nikhlis, A. Iriani, and K. D. Hartomo, "Soft System Methodology (SSM) Analysis to Increase the Number of Prospective Students," INTENSIF J. Ilm. Penelit. dan Penerapan Teknol. Sist. Inf., vol. 4, no. 1, pp. 63-74, 2020.

[16] M. S. Rumetna, D. Manongga, and A. Iriani, "PENERAPAN KNOWLEDGE CAPTURE UNTUK PROMOSI FAKULTAS MENGGUNAKAN SOFT SYSTEM METHODOLOGY ( SSM ) ( STUDI KASUS: FAKULTAS TEKNIK , UNIVERSITAS VICTORY SORONG )," in Prosiding Seminar Nasional Geotik, 2017, pp. 106-116.

[17] M. M. Swastikasari, D. Manongga, and A. Iriani, "Penggunaan Soft System Methodology Dalam Mengevaluasi Permasalahan Pembelajaran Komposisi Pada Mahasiswa Fotografi FTI-UKSW Salatiga," J. Dimens. DKV Seni Rupa dan Desain, vol. 5, no. 1, pp. 57-70, 2020.

[18] E. R. Nainggolan, "Membangun Knowledge Management System untuk Membentuk Knowledge Sharing Menggunakan Metode KM-Roadmap," J. Pilar Nusa Mandiri, vol. 11, no. 1, pp. 60-69, 2015.

[19] F. A. Choirunsyah and H. Heryanto, "Perancangan Knowledge Management System Pada Tenaga Kependidikan Di Perguruan Tinggi," Infomatek, vol. 21, no. 1, pp. 0114, 2019.

[20] K. Angkananon, M. Wald, and P. Ploadaksorn, "Development and testing of a thai website accessibility evaluation tool," Int. J. Electr. Comput. Eng., vol. 10, no. 5, pp. 4900-4909, 2020.

[21] M. S. Rumetna et al., "MENGHITUNG KEUNTUNGAN MAKSIMAL DARI PENJUALAN ROTI ABON GULUNG DENGAN MENGGUNAKAN METODE SIMPLEKS DAN SOFTWARE POM-QM," J. Jendela Ilmu, vol. 1, no. 1, pp. 6-12, 2020.

[22] T. N. Lina et al., "SISTEM INFORMASI E-ARSIP BERBASIS WEB (STUDI 
KASUS : PT HALEYORA POWERINDO CABANG SORONG),” J. Jendela Ilmu, vol. 1, no. 1, pp. 1-5, 2020.

[23] M. S. Rumetna, "AUDIT LINGKUNGAN DAN PENGENDALIAN TEKNOLOGI INFORMASI PADA PT.XYZ,” Simetris J. Tek. Mesin, Elektro dan Ilmu Komput., vol. 9, no. 2, pp. 753-768, 2018.

[24] M. S. Rumetna et al., "Mengoptimalilasi keterbatasan sumber daya untuk memaksimalkan keuntungan penjualan es kelapa muda menggunakan metode simpleks dan software pom-qm," Pengabdi. Masy., vol. 02, no. 02, pp. 136-149, 2019. 